Acta Theriologica 43 (1): 1-11, 1998.

PL ISSN 0001-7051

\title{
Phenetic analysis of Old World Myotis (Chiroptera: Vespertilionidae) based on dental characters
}

\author{
Joanna GODAWA STORMARK*
}

Godawa Stormark J. 1998. Phenetic analysis of Old World Myotis (Chiroptera: Vespertilionidae) based on dental characters. Acta Theriologica 43: 1-11.

Similarities between 42 taxa of genus Myotis were studied based on 11 dental characters. The most primitive conditions were found in subgenus Leuconoe and in most taxa of subgenus Selysius. No clear differences between subgenera Leuconoe and Selysius were found. Only Myotis altarium, M. ikonnikovi, M. mystacinus, and $M$. hosonoi were found to be distinct from the 13 species studied within subgenus Selysius. The subgenus Myotis was distinct from the other subgenera in having the most derived conditions.

Institute of Systematics and Evolution of Animals, Polish Academy of Sciences, Sławkowska 17, 31-016 Kraków, Poland

Key words: Myotis, dental morphology, discrete state characters, cluster analysis

\section{Introduction}

Taxonomy should be principally based upon all available metric and discrete-state characters (Findley 1993). However, studies of the Recent bats, which include discrete-state characters, use mainly external morphology, molecular data and only in few cases dental characters (eg Bogdanowicz 1992, Bogdanowicz and Owen 1992, Volleth and Heller 1994, Morales and Bickham 1995). This is contrasts with the paleontological taxonomy of bats, which is mainly based upon tooth morphology (eg Sevilla 1990, Sigé 1991, Czaplewski 1993). This lack of compatibility between neontological and paleontological taxonomy hinders evaluation of species coherence and definitions. A re-evaluation of the taxonomic value of dental morphology on Recent bats suggets that these characters have a higher power of discrimination than traditional external and skeletal characters (Sevilla and Lopez-Martinez 1986).

The aim of this study was to provide dental character distribution of the Recent taxa in the genus Myotis. Species of this genus are the most common among fossil microchiropteran remains and are therefore well suited for studies of taxonomy.

* Present address: Preclinical Division, University of Bergen, Årstadveien 19, 5009 Bergen, Norway 
A phenetic analysis of dental characters was used to compare the subgenera. Some phylogenetic suggestion are also given. Taxa from the Old World were selected because bats of genus Myotis likely originated there (Findley 1972). Classification of bats to subgenera follows Koopman (1994).

\section{Material and methods}

In totals 433 skulls of 42 taxa of the genus Myotis were examined (Appendix). Thirteen characters were coding using the terminology of Menu $(1985,1987)$ and Sevilla and Lopez-Martinez (1986). All characters were checked for intraspecific variability in Myotis mystacinus which included the largest number of specimens studied $(n>50)$. Two characters were excluded due to high variability: the number of grooves in upper canines and the shape of the cingulum of $\mathrm{P}^{4}$ at labial view, leaving 11

Table 1. Morphological characters used in analysis and their coded conditions.

\begin{tabular}{|c|c|c|c|}
\hline Character & Condition & Code & See Figure \\
\hline 1. First upper incisor $\mathrm{I}^{1}$ & $\begin{array}{l}\text { condition } 1 \\
\text { condition } 2 \\
\text { condition } 3\end{array}$ & $\begin{array}{l}0 \\
1 \\
2\end{array}$ & 1 \\
\hline 2. Cingular cusplet/cusp at margin of $\mathrm{P}^{4}$ & $\begin{array}{l}\text { with well developed cusplet } \\
\text { with little cusplet } \\
\text { absent }\end{array}$ & $\begin{array}{l}0 \\
1 \\
2\end{array}$ & 2 \\
\hline 3. Heel of $\mathrm{P}^{4}$ & $\begin{array}{l}\text { well developed } \\
\text { slightly developed }\end{array}$ & $\begin{array}{l}0 \\
2\end{array}$ & 3 \\
\hline 4. First two upper molars $\mathrm{M}^{1}$ and $\mathrm{M}^{2}$ & $\begin{array}{l}\text { with paraloph } \\
\text { without paraloph }\end{array}$ & $\begin{array}{l}0 \\
2\end{array}$ & 4 \\
\hline 5. as above & $\begin{array}{l}\text { with metaconule } \\
\text { without metaconule }\end{array}$ & $\begin{array}{l}0 \\
2\end{array}$ & 4 \\
\hline 6. as above & $\begin{array}{l}\text { with metaloph } \\
\text { without metaloph }\end{array}$ & $\begin{array}{l}0 \\
2\end{array}$ & 4 \\
\hline 7. as above & $\begin{array}{l}\text { with paraconule } \\
\text { without paraconule }\end{array}$ & $\begin{array}{l}0 \\
2\end{array}$ & 4 \\
\hline 8. as above & $\begin{array}{l}\text { protofossa closed } \\
\text { protofossa opened }\end{array}$ & $\begin{array}{l}0 \\
2\end{array}$ & 4 \\
\hline 9. Cingular cusplet of lower C & $\begin{array}{l}\text { present } \\
\text { absent }\end{array}$ & $\begin{array}{l}0 \\
2\end{array}$ & 5 \\
\hline 10. Cingular platform of lower $\mathrm{C}$ & $\begin{array}{l}\text { well developed } \\
\text { minimally developed }\end{array}$ & $\begin{array}{l}0 \\
2\end{array}$ & 6 \\
\hline 11. Talonid of lower $\mathrm{M}_{3}$ & $\begin{array}{l}\text { not reduced } \\
\text { reduced }\end{array}$ & $\begin{array}{l}0 \\
2\end{array}$ & 7 \\
\hline
\end{tabular}




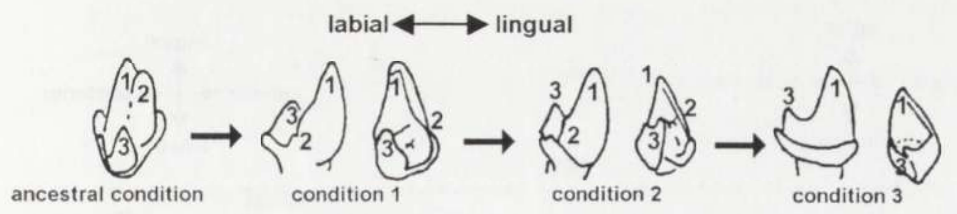

Fig. 1. Development of first upper incisor. Drawings on Figs 1-7 are after Menu (1985).

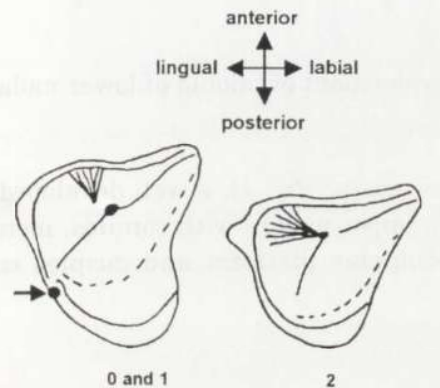

Fig. 2. Development of cusp at margin of $\mathrm{P}^{4}$ (condition 0 and 1 together).

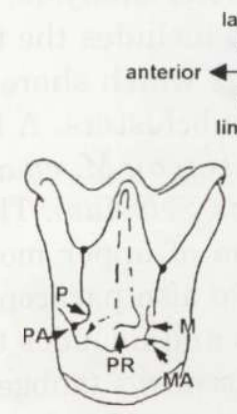

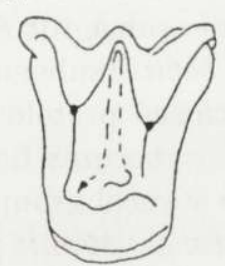

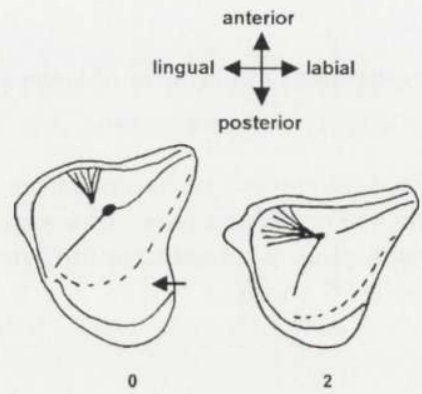

Fig. 3. Development of heel of upper premolar $\mathrm{P}^{4}$.
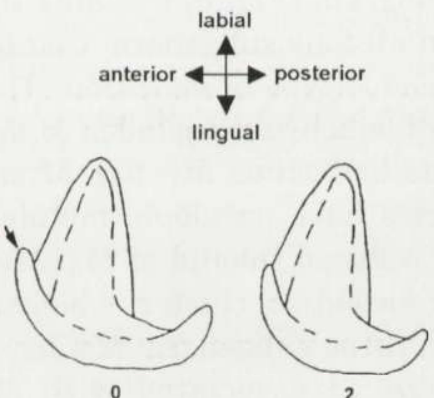

Fig. 5. Development of cingular cusplet of lower canine.
Fig. 4. Development of upper molars $\mathrm{M}^{1}$ and $\mathrm{M}^{2}$. PA - paraconule, MA - metaconule, $\mathrm{P}$ paraloph, M - metaloph, PR - protofossa. characters for remaining analyses (Table 1). Clustering of the taxa was done by unweighted pair-group using arithmetic averages (UPGMA, Sneath and Sokal 1973) based on simple matching coefficient. The cluster analysis was performed with the NTSYS-pc (version 1.80) sofware package. The cophenetic correlation was used as a measure of goodness of fit for a cluster analysis (Rohlf 1994). The following characters being characteristic for genus Stehlinia were defined as ancestral forms and 


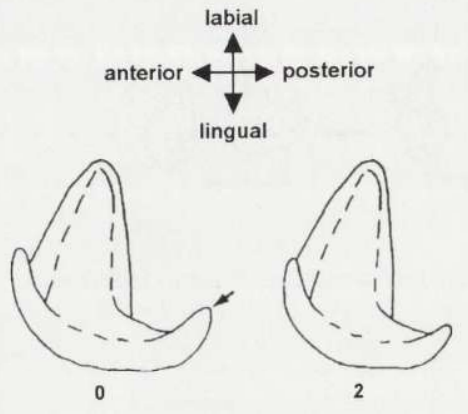

Fig. 6. Development of platform of lower canine.
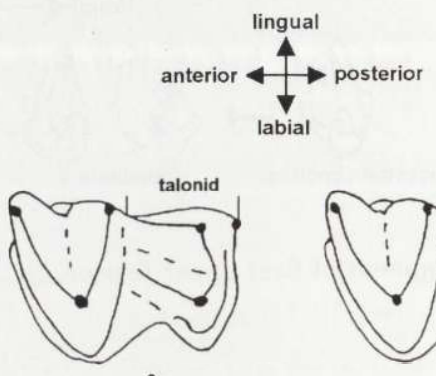

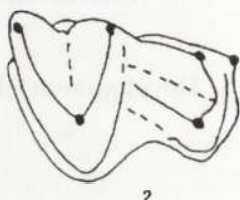

2

Fig. 7. Development of talonid of lower molar $\mathrm{M}_{3}$.

checked for development in Recent forms: $\mathrm{I}^{1}$ - condition 1 (three cusps; Fig. 1); a well developed heel and presence of cingular cusplet at margin of $\mathrm{P}^{4}$ (Figs 2 and 3); upper molars with conules, metaloph and paraloph (Fig. 4); lower canine with a well developed cingular platform and cusplet on the cingulum (Figs 5 and 6 ).

\section{Results}

\section{Phenetic procedure}

The cophenetic correlation $(r=0.83)$ showed good fit for cluster analysis. The phenogram (Fig. 8) contains three major clusters. The first one includes the taxa from all four subgenera: Cistugo, Myotis, Leuconoe, and Selysius which share the Leuconoe type of dentition. This cluster is divided into three subclusters. A first small subcluster includes $M$. lesueuri, M. seabrai (subgenus Cistugo), M. emarginatus (subgenus Myotis), M. annectans and M. scotti (subgenus Selysius). These species have paraloph, metaloph, metaconule, closed protofossa of upper molars and reduced talonid of $\mathrm{M}_{3}$. Myotis scotti and $M$. annectans have also paraconule. The second subcluster is bigger and divided into several groups and includes taxa from three subgenera: Myotis, Selysius and Leuconoe. Myotis formosus (subgenus Myotis) is associated with M. muricola (subgenus Selysius) and M. bocagei (subgenus Leuconoe). Myotis formosus has metaloph, paraloph and metaconule which is characteristic for subgenus Leuconoe. $\mathrm{I}^{1}$ is provided with three cusps. Selysius species within the second subcluster (M. muricola, M. ridleyi, M. rosseti, $M$. siligorensis) have paraconule (the only exception being $M$. muricola), metaconule, paraloph and metaloph on upper molars. Myotis ridleyi and M. rosseti have the first upper incisor with three cups. Leuconoe taxa and one Selysius (M. brandti) belong to the third subcluster. Myotis brandti has good developed paraconule, metaconule, paraloph and metaloph on upper molars.

A second small cluster is formed by $M$. bechsteini, M. frater and M. ater. These three species have intermediate type of dentition. 


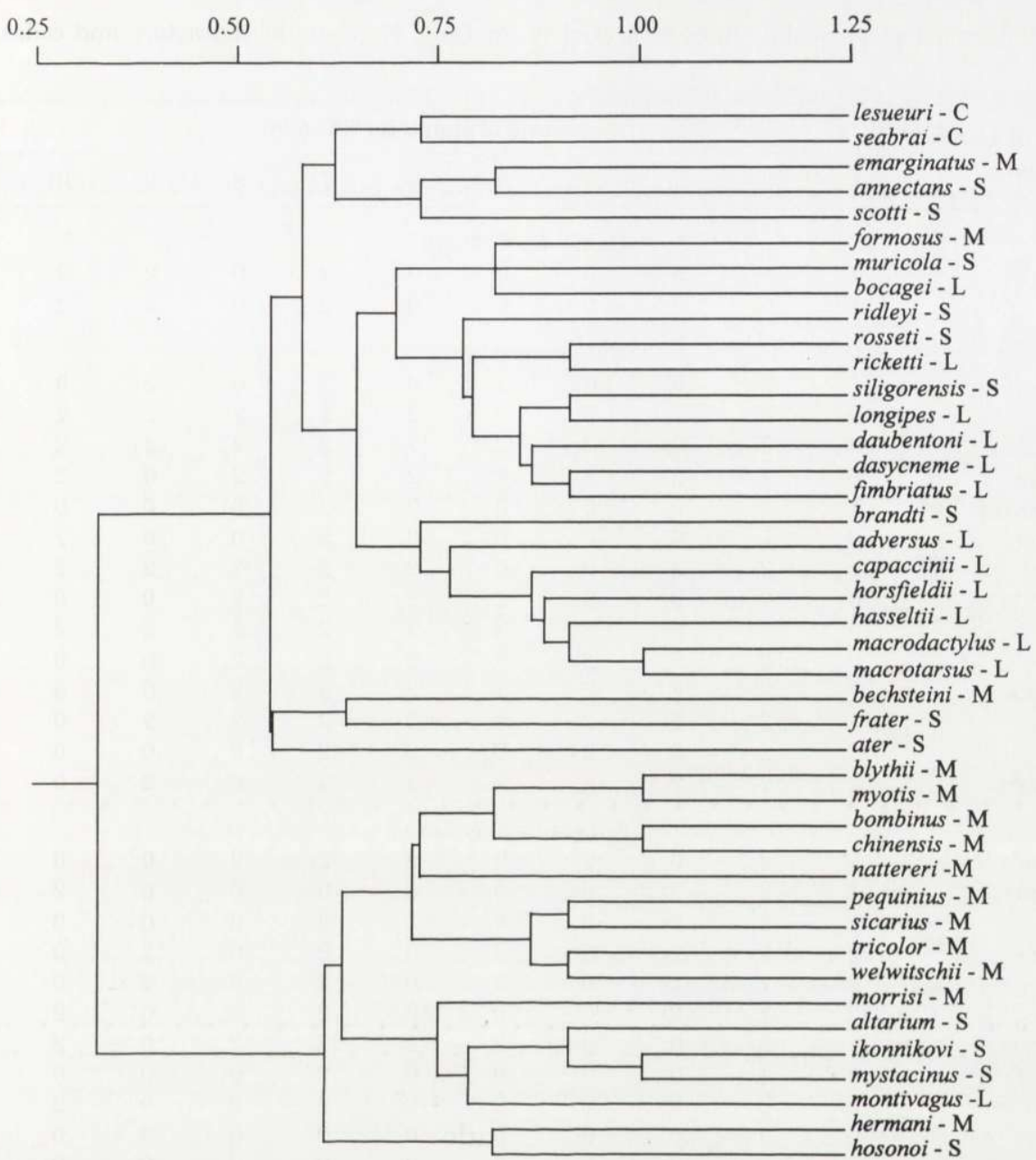

Fig. 8. Phenogram for average taxonomic distances between Myotis bat species based on matrix of simple-matching coefficient. Subgenera: C - Cistugo, L - Leuconoe, M - Myotis, S - Selysius.

The last third cluster contains the species of the subgenera Myotis and Selysius. One exception is $M$. montivagus which belongs to subgenus Leuconoe. This species has paraloph, but metaloph, metaconule and paraconule are absent. First upper incisor has two cusps. Taxa of this cluster are characteristic by a more derived type of dentition.

The matrix of dental characters (Table 2) shows differences between the subgenus Myotis and other subgenera. Most species of the subgenus Myotis have derived character states (eg different from those in the genus Stehlinia). Subgenus Leuconoe shows the most primitive states among all subgenera. 
Table 2. Morphological dental characters used in analysis. Numbers of characters and codes as in Table 1.

\begin{tabular}{|c|c|c|c|c|c|c|c|c|c|c|c|}
\hline \multirow{2}{*}{$\begin{array}{c}\text { Species of genus } \\
\text { Myotis }\end{array}$} & \multicolumn{11}{|c|}{ State of character (in code) } \\
\hline & 1 & 2 & 3 & 4 & 5 & 6 & 7 & 8 & 9 & 10 & 11 \\
\hline \multicolumn{12}{|c|}{ Subgenus Cistugo } \\
\hline lesueuri & 1 & 1 & 2 & 0 & 0 & 0 & 2 & 0 & 2 & 2 & 2 \\
\hline seabrai & 1 & 0 & 0 & 0 & 0 & 0 & 2 & 0 & 2 & 2 & 0 \\
\hline \multicolumn{12}{|c|}{ Subgenus Myotis } \\
\hline bechsteini & 1 & 2 & 0 & 0 & 2 & 0 & 2 & 0 & 2 & 0 & 0 \\
\hline blythii & 0 & 2 & 2 & 2 & 2 & 2 & 2 & 2 & 2 & 2 & 2 \\
\hline bombinus & 0 & 2 & 2 & 2 & 2 & 2 & 2 & 2 & 2 & 2 & 0 \\
\hline chinensis & 0 & 2 & 2 & 2 & 2 & 2 & 2 & 2 & 0 & 2 & 0 \\
\hline emarginatus & 1 & 2 & 2 & 0 & 0 & 0 & 2 & 0 & 0 & 0 & 2 \\
\hline formosus & 0 & 1 & 0 & 0 & 0 & 0 & 2 & 0 & 0 & 2 & 0 \\
\hline hermani & 2 & 2 & 2 & 0 & 0 & 2 & 2 & 2 & 2 & 2 & 2 \\
\hline morrisi & 0 & 2 & 0 & 0 & 2 & 2 & 2 & 2 & 0 & 0 & 0 \\
\hline myotis & 0 & 2 & 2 & 2 & 2 & 2 & 2 & 2 & 2 & 2 & 2 \\
\hline nattereri & 0 & 2 & 2 & 2 & 0 & 2 & 2 & 2 & 0 & 0 & 0 \\
\hline pequinius & 1 & 2 & 2 & 2 & 2 & 2 & 2 & 2 & 0 & 0 & 2 \\
\hline sicarius & 1 & 2 & 2 & 2 & 2 & 2 & 2 & 2 & 2 & 0 & 2 \\
\hline tricolor & 2 & 2 & 2 & 2 & 2 & 2 & 2 & 2 & 0 & 0 & 2 \\
\hline welwitschii & 2 & 2 & 2 & 2 & 2 & 2 & 2 & 2 & 2 & 0 & 2 \\
\hline \multicolumn{12}{|c|}{ Subgenus Selysius } \\
\hline altarium & 2 & 2 & 0 & 2 & 2 & 2 & 2 & 2 & 0 & 0 & 0 \\
\hline annectans & 1 & 2 & 2 & 0 & 0 & 0 & 0 & 0 & 0 & 2 & 2 \\
\hline ater & 2 & 2 & 2 & 2 & 0 & 0 & 2 & 0 & 0 & 0 & 0 \\
\hline brandti & 2 & 0 & 2 & 0 & 0 & 0 & 0 & 0 & 2 & 0 & 0 \\
\hline frater & 2 & 1 & 2 & 0 & 2 & 0 & 2 & 0 & 2 & 0 & 2 \\
\hline hosonoi & 2 & 2 & 2 & 0 & 0 & 2 & 2 & 2 & 0 & 2 & 0 \\
\hline ikonnikovi & 2 & 2 & 0 & 2 & 2 & 2 & 2 & 2 & 0 & 2 & 0 \\
\hline muricola & 2 & 1 & 0 & 0 & 0 & 0 & 2 & 0 & 0 & 0 & 0 \\
\hline mystacinus & 2 & 2 & 0 & 2 & 2 & 2 & 2 & 2 & 0 & 2 & 0 \\
\hline ridleyi & 0 & 0 & 0 & 0 & 0 & 0 & 0 & 0 & 0 & 0 & 2 \\
\hline rosseti & 0 & 2 & 0 & 0 & 0 & 0 & 0 & 0 & 0 & 0 & 0 \\
\hline scotti & 2 & 1 & 2 & 0 & 0 & 0 & 0 & 0 & 0 & 2 & 2 \\
\hline siligorensis & 0 & 0 & 0 & 0 & 0 & 0 & 0 & 0 & 2 & 0 & 0 \\
\hline \multicolumn{12}{|c|}{ Subgenus Leuconoe } \\
\hline adversus & 0 & 2 & 2 & 0 & 2 & 0 & 0 & 0 & 2 & 0 & 0 \\
\hline bocagei & 2 & 1 & 0 & 0 & 0 & 0 & 0 & 0 & 0 & 2 & 0 \\
\hline capaccinii & 0 & 0 & 2 & 0 & 0 & 0 & 0 & 0 & 2 & 2 & 0 \\
\hline daubentoni & 0 & 1 & 0 & 0 & 0 & 0 & 0 & 0 & 0 & 0 & 0 \\
\hline dasycneme & 0 & 1 & 0 & 0 & 0 & 0 & 0 & 0 & 2 & 0 & 2 \\
\hline fimbriatus & 0 & 1 & 0 & 0 & 0 & 0 & 0 & 0 & 2 & 0 & 0 \\
\hline horsfieldii & 0 & 2 & 0 & 0 & 0 & 0 & 0 & 0 & 2 & 2 & 0 \\
\hline hasseltii & 1 & 2 & 2 & 0 & 0 & 0 & 0 & 0 & 2 & 2 & 0 \\
\hline longipes & 0 & 2 & 0 & 0 & 0 & 0 & 0 & 0 & 2 & 0 & 0 \\
\hline macrodactylus & 0 & 2 & 2 & 0 & 0 & 0 & 0 & 0 & 2 & 2 & 0 \\
\hline macrotarsus & 0 & 2 & 2 & 0 & 0 & 0 & 0 & 0 & 2 & 2 & 0 \\
\hline montivagus & 2 & 2 & 0 & 0 & 2 & 2 & 2 & 2 & 0 & 2 & 0 \\
\hline ricketti & 0 & 2 & 0 & 0 & 0 & 0 & 2 & 0 & 0 & 0 & 0 \\
\hline
\end{tabular}




\section{Discussion}

\section{Primitive state of characters}

Menu (1987) proposed theoretical basic characters of dentition, which agree with dentition characters of Stehlinia (Sigé 1974). This genus, known from Quercy, France (late Eocene, early Oligocene) is assumed to have an ancient vespertlionid's type of dentition (Menu 1985, 1987). Further evolution of dentition can be studied in relation to this genus. Its first upper incisor has three well developed cusps (Fig. 1). The upper premolar $\mathrm{P}^{4}$ has a cusp and a well developed heel (Figs 2 and 3). The upper molars $\mathrm{M}^{1}$ and $\mathrm{M}^{2}$ have well developed paraconule, metaconule with strong metaloph, and paraloph (Fig. 4). The lower canine bears a well developed cingular platform and cusp (Figs 5 and 6). A talonid of $\mathrm{M}_{3}$ is larger than the trigonid, not reduced (Fig. 7). States of characters characteristic for Stehlinia are hence presumed to be primitive. The three cusps of first upper incisor make the most primitive state of character within the genus Myotis, but they are, however, different from that of the genus Stehlinia. Condition 1 of development of $\mathrm{I}^{1}$ is called here a primitive state of character.

\section{Description of subgenera}

Subgenus Myotis: Myotis myotis (type species), M. blythii and M. welwitschii have the most modern type of dentition within subgenus. All characters (except the development of upper first incisors in M. myotis, M. blythii, and a well developed cingular platform in lower canine in $M$. welwitschii) are of derived state. Myotis formosus has only two derived states of characters, ie 7 and 10 (Table 1). Other characters look like in genus Stehlinia.

Subgenus Selysius: Development of $\mathrm{I}^{1}$ (namely, the connection between third and first cusp, and space disappeared) distinguishes this subgenus from Leuconoe. Among Leuconoe taxa only $M$. bocagei and $M$. montivagus has $\mathrm{I}^{1}$ in condition 3 . Myotis montivagus, regarded as belonging to the subgenus Selysius by Corbet and Hill (1991), was transferred to the subgenus Leuconoe by Koopman (1994). Myotis mystacinus and $M$. ikonnikovi have generally the most derived character states within the subgenus. Only three characters have primitive states: a well developed heel on upper $\mathrm{P}^{4}$, cingular cusplet of lower canine present, and not reduced talonid of lower third molar. Numerous species of the subgenus Selysius have dental characters similar to bats of the subgenus Leuconoe. For instance, Myotis annectans, $M$. brandti, $M$. ridleyi, $M$. rosseti, $M$. scotti, and $M$. siligorensis have paraconule and metaconule, which are characteristic for Leuconoe forms.

Subgenus Cistugo: Two African species, Myotis lesueuri and M. seabrai, belong to this subgenus. Both species have $\mathrm{I}^{1}$ of intermediate condition 2 , ie the second cusp disappears (Fig. 1: condition 2). The primitive character states of both species are: presence of metaconule, paraloph and metaloph, and protofossa closed. Myotis seabrai has two additional primitive characters: cusp at margin of $\mathrm{P}^{4}$ and a well developed talonid. Dentition of Cistugo species is of the Leuconoe type. 
Subgenus Leuconoe: Taxa of this subgenus have the most primitive type of dentition within the genus Myotis. Only two character states are derived in a majority of Leuconoe taxa: lack of cusp at margin of $\mathrm{P}^{4}$ and at lower canine. All Leuconoe taxa have paraconule (except $M$. montivagus and $M$. ricketti). Without any doubt, the presence of conules is a primitive structure. Slaughter (1970) wrote that in course of evolution the bats of genus Myotis have lost conules of upper molars. Tate (1941) suggested, that presence of a paraconule is characteristic for Leuconoe forms and not for the subgenus Selysius. However, almost half of the taxa of subgenus Selysius examined here have paraconule (Table 2).

\section{Conclusions}

Taxa of subgenus Myotis could be separated from those of three other subgenera (Fig. 8, Table 2). Miller and Allen (1928) wrote that this subgenus "is not connected by intermediate stages of structure with any other members of the genus". Except for the development of first upper incisor, the other characters have derived character states in most species of this genus. Menu (1987) includes in the subgenus Myotis only two species: M. myotis and M. blythii. Species of this subgenus are very large, contrary to most species of other subgenera (excluding M. ricketti). All representatives of subgenus Myotis had lost the paraconule in upper molars. Almost all species are separated in the phenogram (excluding $M$. bechsteini, $M$. formosus and $M$. emarginatus). Myotis hermani is listed as subspecies of $M$. formosus by Koopman (1994), but these species are different in dentitition characters and general size of body.

Most species of subgenera Selysius and Leuconoe are mixed in the phenogram. Exceptions are M. altarium, M. ikonnikovi, M. mystacinus, M. hosonai (Selysius), and $M$. montivagus (Leuconoe). As was told above, representatives of both subgenera show similarities. Menu (1987) proposed to combine subgenera Selysius and Leuconoe into one subgenus Leuconoe, but his proposition has not been generally accepted. It is difficult to find sharp boundary between these two subgenera based solely on dental characters. Leuconoe "daubentoni" type of dentition is the most primitive among genus Myotis. There is no Selysius type of dentition; all Selysius species have more or less Leuconoe type. Among this subgenus only $M$. altarium, $M$. hosonai, $M$. ikonnikovi, and $M$. mystacinus have the more derived character states. Myotis ikonnikovi was included to "muricola" group by Koopman (1994), but this species is more similar to M. mystacinus in dentition structure and shape of skull. Both Cistugo species (M. lesueuri, M. seabrai) have Leuconoe type of dentition, but their wing-glands distinguish this subgenus from the others.

This is suggested to leave three subgenera in genus Myotis: Myotis, Leuconoe and Cistugo. Bats of subgenus Selysius should be included to subgenus Leuconoe. 
Acknowledgments: The following persons and institutions have kindly permitted me to loan and use specimens in their care: P. D. Jenkins, British Museum (Natural History), London, Great Britain (BMNH); D. Harrison, Harrison Zoological Museum, Sevenoaks, Great Britain (HZM); F. Spitzenberger, Naturhistorisches Museum Wien, Austria (NMW); C. Smeenk, Rijksmuseum van Natuurlijke Historie, Leiden, Holland (RNHL); M. Tranier, Musum National d'Histoire naturelle, Paris, France (MZP); L. Cederholm, Zoologiska Institutionen, Lund, Sweden (MZL); A. Keller, Muséum d'Histoire Naturelle, Geneva, Switzerland (MHNG); G. Topál, Hungarian Natural History Museum, Budapest, Hungary (HNHM); P. Strelkov, Zoological Museum of Academy of Sciences, St. Petersburg, Russia (ZISP); G. Storch, Senckenberg Museum, Frankfurt am Main, Germany (SMF); R. Hutterer, Museum Alexander Koenig, Bonn, Germany (MAK); K. Kowalski, Institute of Systematics and Evolution of Animals, Kraków, Poland (ISEZ), F. Uribe, Museum of Zoology, Barcelona, Spain (MZB); Z. Pucek, Mammal Research Institute, Białowieża, Poland (ZBS). I am also gratefull L. Kirkendall, Department of Zoology, Bergen, Norway, for correcting my English.

\section{References}

Bogdanowicz W. 1992. Phenetic relationships among bats of the family Rhinolophidae. Acta Theriologica 37: 213-240.

Bogdanowicz W. and Owen R. D. 1992. Phylogenetic analyses of the bat family Rhinolophidae. Zeitschrift für Zoologische Systematik und Evolutionsforschung 30: 142-160.

Corbet G. B. and Hill J. E. 1991. A world list of mammalian species, 3rd ed. Natural History Museum Publications and Oxford University Press, London: 1-243.

Czaplewski N. J. 1993. Late Tertiary bats (Mammalia, Chiroptera) from the southwestern United States. Southwestern Naturalist 38: 111-118.

Findley J. S. 1972. Phenetic relationships among bats of the genus Myotis. Journal of Mammalogy 21: 31-52.

Findley J. S. 1993. Bats. A community perspective. Cambridge University Press, Cambridge: 1-67.

Koopman K. P. 1994. Chiroptera: Systematics. Hanbook of Zoology, Vol. VIII, Mammalia. Walter de Gruyter, Berlin: 1-217.

Menu H. 1985. Morphotypes dentaires actuels et fossiles des chiroptres Vespertilioninés. I Partie: Berlin, Étude des morphologies dentaires. Paleoverterbrata 15: 71-128.

Menu H. 1987. Morphotypes dentaires actuels et fossiles des chiroptres Vespertilioninés. II Partie: implications systematiques et phylogeniques. Paleoverterbrata 17: 77-150.

Miller G. S. and Allen G. M. 1928. The American bats of the genera Myotis and Pizonyx. Bulletin of the United States National Museum 144: 1-218.

Morales J. C. and Bickham J. 1995. Molecular systematics of the genus Lasiurus (Chiroptera: Vespertilionidae) based on restriction-site maps of the mitochondrial ribosomal genes. Journal of Mammalogy 76: 730-749.

Rohlf F. J. 1994. NTSYS-pc numerical taxonomy and multivariate analysis system, ver. 1.80. Exeter Software: Setauket, New York.

Sevilla P. 1990. The fauna of bats from the upper pleistocene locality of Santenay (Côte-d'Or, France). Quaternaire 2: 101-110.

Sevilla P. and Lopez-Martinez N. 1986. Comparative systematics value between dental and external/skeletal features in western European Chiroptera. [In: Teeth Revisited. Proceedings of the 7th International Symposium on Dental Morphology. D. E. Russel, J. P. Santoro and D. Sigogneau-Russel, eds]. Mémoíres du Muséum National d'Histoire Naturelle, Paris: (Sèrie C) 53: $255-266$.

Sigé B. 1974. Données nouvelles sur le genre Stehlinia (Vespertilionidae: Chiroptera) du paléogne d'Europe. Paleoverterbrata 6: 253-272.

Sigé B. 1991. Rhinolophoidea et Vespertilionoidea (Chiroptera) du Chambi (Eocene inferieur de Tunisie). Aspects Biostratigraohique, Biogeographique et Paleoecologique de l'Origine des Chiropteres Modernes 182: 355-376. 
Slaughter B. H. 1970. Evolutionary trends of chiropteran dentition. [In: About Bats: A chiropteran biology symposium. B. H. Slaughter and D. W. Walton, eds]. Southern Methodist University Press, Dallas: $51-83$

Sneath P. H. A. and Sokal R. R. 1973. Numerical taxonomy. The principles and practice of numerical classification. W. H. Freeman and Co., San Francisco: 1-573

Tate G. H. H. 1941. Results of the Archbold expeditions. no. 39. A review of the genus Myotis (Chiroptera) of Eurasia, with special reference to species occurring in the East Indies. Bulletin of the American Museum of Natural History 78: 537-765.

Volleth M. and Heller K. G. 1994. Phylogenetic relaionships of vespertilionid genera (Mammalia: Chiroptera) as revealed by karyological analysis. Zeitschrift für Zoologische Systematik und Evolutionsforschung 31: 11-34.

Received 7 September 1994, revised 24 May 1997, accepted 4 July 1997.

Appendix. List of examined specimens. Museum acronyms for specimens used in this study are defined in the acknowledgments section. Number in parentheses after localities indicates the number of specimens examined from that locality. Number in parentheses after species name indicates total number examined.

Myotis adversus (7) - Borneo (2): BMNH - 95.8.4.2, 95.8.41; Java (5): 9.1.5.396, 9.1.5.400, 9.1.5.398, 9.1.5.408, 15.2.21.3.

M. altarium (5) - China (5): BMNH - 11.2.1.7, 11.2.1.8, 11.2.1.10-11.2.1.12.

M. annectans (1) - Thailand (1): BMNH - 78.2355.

M. ater (2) - Siberut (2): BMNH - 28.2933, 78.2934.

M. bechsteini (19) - Hungary (9): HNHM - 56.611, 71.2.1, 2937, 73.110.1, 57.37.1, 55.17.1, 71.1.1, 57.89.1, 57.59.1; Germany (3): SMF - 9930, 47445, 3332; Holland (1): RNHL - 4260; France (3): MZP - 1975.730, 1962.1791, 1920.79; Sweden (1): MZL - L935/3995; Poland (2): ISEZ $\mathrm{M} / 1021 / 59, \mathrm{M} / 6235 / 84$

M. blythii (37) - Austria (13): NHW - 11580, 14328, 18815, 18844, 29410, 29411, 39170-39176; Italy (1): 12065; Slovenija (14): 28832-28845; Spain (9): MZB - 82-7273, 82-6761, 84-9322, 84-9323a, 84-9323b, 84-9324, 84-9326, 94-9328, 85-0226.

M. bombinus (4) - Japan (4): BMNH - 6.1.4.14 (type), 6.1.4.15, 6.1.4.13, 6.1.4.17.

M. brandti (27) - Austria (12): NMW - 29420-29423, 29826, 30395, 30396, 30381, 30404, 30418, 30420, 30429; Czechoslovakia (3): 11163; IZB - 1.187, 1.188; Poland (5): ZBS - 961091510; ISiW - M/15030/10, M/15040/90, M/14616/20, M/15031/10; Switzerland (2): MHNG - 1684.71, 943.71; Holland (3): RNHL - 12011, 12193, 3677; Russia (European part) (2): NMW - 15198, 30426

M. capaccini (14) - Austria (1): NMW - 33298; Greece (1): 27559; Slovenija (12); 15715-15717, 18924, 30335-30337, 30339-30342, 30380.

M. chinensis (2) - China (1): BMNH - 54.2.8.2 (type); Vietnam (1): HNHM - 32 .

M. dasycneme (30) - Hungary (9): HNHM - 56.84.1, 2460/1, 57.171.1, 56.85.1, 56.87.1, 71.3.1, 3741.2, 57.89.1, 54.87.1; Holland (10): RNHL - 12297, 12311, 12267, 11067, 29075, 12276, 11108, 12266 , 12289, 12278; Russia (European part) (11): ZISP - 76452, 25770, 25772, 25771, 38540, 25765, 41717, 76453, 72426, 70312, 76451 .

M. daubentoni (34) - Austria (19): NMW - 12026, 14630, 29042, 29044-29048, 29451, 29464, 29848, 30390, 30391, 30401, 30414, 30437-30439, 34221; Poland (15): ZBS - 146159, 146160, 150309, 150333-150335, 150338, 150342, 150344, 150345, 150347, 150348, 150391, 150397, 150404. 
M. emarginatus (17) - Hungary (9): HNHM - 56.55.2, 2419.1, 71.7.1, 2419.9.3, 56.105.1, 2420/172, 2957.6, 58.41.1, 59.130.1; Bulgaria (1): ZISP - 48067; Holland (5): RNHL - 29061, 29059, 12159, 12173, 12335; Slovenija (1): ZISP - 31422; Italy (1): SMF - 12052.

$M$. fimbriatus (2) - China (2): BMNH - 70.7.18.9, 10.7.8.10.

M. formosus (11) - Formosa (1): BMNH - 66.6.17.1; India (3): 6.12.2.41, 79.11.21.175, 79.11.21.176; Tibet (1): 15.2.21.14; Taiwan (6): RNHL - 19705, 29021, 20923-20926.

M. frater (11) - Japan (2): ZISP - 59097, 72227; south-eastern Russia (9): 9295, 9303, 77171, 50710, 9309, 71988, 9293, 8888, 9301.

M. hasseltii (16) - Burma (1): BMNH - 78.154; Java (1): 60.319.1378; Thailand (1): 9.10.11.9; Thailand (1): 79.1414; Malaya (1): 68.842; Vietnam (11): HMNH - 73, 74, 76, 82-84, 205, 232, 286, $386,387$.

M. hermani (1) - Indonesia (1): BMNH - 23.12.13.

M. horsfieldii (5) - Celebes (1): BMNH - 73.1804; Java (1): 9.1.5.383; Malaysia (1): 73.616; Thailand (2): $79.1415,79.1416$.

M. hosonoi (3) - Japan (3): BMNH - 70.2523, IZSP: 59098, 59099.

M. ikonnikovi (8) - Baikal (1): IZSP - 5101; south-eastern Russia (5): 5375, 63809, 30451, 77632, 77142; Manchuria (1): 9254; Mongolia (1): 5190.

M. lesueuri (1) - South Africa (1): BMNH - 27.4.13.

M. longipes (22) - Afghanistan (2): IZSP - 58447, 58448; India (20): HNHM - 472-474, 476, 478, $480-483,493,499,501,502,504-508,510,511$.

M. macrodactylus (7) - Japan (7): HZM - 1.2563; BMNH - 6.1.4.6-6.1.4.11.

M. macrotarsus (1) - Philippines (1): BMNH - 978.4.3.

M. montivagus (2) - India (1): BMNH - 1.2563 (type); Malaysia (1) - 83.349.

M. morrisi (1) - Niger (1): BMNH - 84.840 .

M. muricola (10) - Borneo (1): HNHM - 2869/23-2; Sumatra (1) - 2869/3; Java (4): BMNH - 6.1.4.7, 6.1.4.8, 9.15.375, 10.4.6.27; Malaysia (4): 1.3.9.6, 65.338-65.340.

M. myotis (30) - Poland (18): ISEZ - M/3024/66, M/3025/66, M/3028/66, M/5591/80-M/5594/80, M/5596/80, M/5597/80, M/5600/80-M/5604/80, M/5611/80, M/5612/80, M/5614/80, M/5617/80, M/5617/80, M/5618/80, M/5621/80, M/5622/80, M/5624/80, M/5626/80-M/5629/80, M/5631/80, $\mathrm{M} / 5632 / 80, \mathrm{M} / 6281 / 85$.

M. mystacinus (57) - Austria (23): NMW - 10100, 11578, 11584, 11585, 11894, 12019, 12117, 12121, 12883, 14324, 15128, 15708, 15983, 19951, 27477, 29122, 29125, 34208-34213; Germany (31): SMF - 3324, 3328-3334, 3339, 3528, 4595, 9059, 9065, 9064, 9066, 9068, 9073, 9075, 9076, 9092, 9094, 9066; MAK - 39.790, 46.413, 53.169, 57.195, 79.181-79.184, 79.240; Holland (3): NMW 16836, 18884, 18884.

M. nattereri (12) - Spain (7): IZB - 84-9317-84-9320, 84-9318b, 84-9318c, 84-9318d; Poland (5): ZBS - 110207, 115826, 115822; NMW - 42510, 42511.

$M$. pequinius (2) - China (2): BMNH - 8.8.7.3, 26.2.3.4.

$M$. ricketti (4) - China (3): BMNH - 8.7.25.8, 88.326, 26.11.15.8, 94.1.1.22.

M. ridleyi (5) - Borneo (1): BMNH - 82.553; Malaysia (4): 84.1983, 67.16004, 98.3.13.6, 83.75.

M. rosseti (4) - Thailand (3): HNHM - 2869/5, 2869/51; BMNH - 74.336; Cambodia (1): 68.1194

M. scotti (3) - Ethiopia (3): BMNH - 27.3.4.6, 60.340, 71.673.

M. seabrai (1) - South Africa (1): BMNH - 25.1.2.6.

M. sicarius (3) - India (1): BMNH - 91.10.7.56 (type); Nepal (2): 23.1.9.4, 23.1.9.5.

M. siligorensis (5) - India (1): HNHM - 763; Vietnam (1): 98; Malaysia (1): BMNH - 67.219; Thailand (2): $79.1417,21.1 .10 .19$.

M. tricolor (6) - Ethiopia (1): BMNH - 37.2.14.13; Malawi (1): 87.1082; South Africa (1): 14.5.4.2; Uganda (3): 40.741, 40.740, 64.172.

M. welwitschii (3) - South Africa (1): BMNH - 0.11.6.1; Malawi (2): 22.12.17.75, 22.12.17.76. 